\title{
Structure of the littoral fish assemblage in an impounded tributary: the effects of macrophytes presence (subtropical region, Brazil)
}

\author{
Hermes-Silva, S. ${ }^{a, b *}$ and Zaniboni-Filho, E. ${ }^{b}$ \\ aPrograma de Pós-graduação em Ecologia e Recursos Naturais, Universidade Federal de São Carlos - UFSCar, \\ Rod. Washington Luiz, Km 235, CP 676, CEP 13565-905, São Carlos, SP, Brazil \\ baboratório de Biologia e Cultivo de Peixes de Água Doce - LAPAD, Universidade Federal de Santa Catarina - UFSC, \\ Rod. SC 406, Km 3, 3532, CEP 88066-000, Florianópolis, SC, Brazil \\ *e-mail: samara@lapad.ufsc.br \\ Received July 5, 2011 - Accepted October 28, 2011 - Distributed August 31, 2012
}

(With 2 figures)

\begin{abstract}
To evaluate the effects of macrophytes presence in the structure of littoral fish assemblages in the littoral zone, monthly samples were collected from September, 2006 to August, 2007 in an impounded tributary of the Itá Reservoir, the Fragosos River, located in the Upper Uruguay River Basin. Fish were collected using a beach seine and sampling was conducted in the littoral zone inside a macrophyte stand and in an area with no macrophytes. A total of 5,191 fish were captured during the study period. Fish assemblage attributes (fish abundance, species richness, and diversity) varied significantly between sampling months and areas. The abundance of Astyanax cf. bimaculatus, Astyanax fasciatus, Geophagus brasiliensis, and Gymnotus carapo also varied significantly between sampling months and areas. Detrended Correspondence Analysis showed a clear spatial segregation at the first axis and a slight temporal segregation at the second axis. These results were confirmed by Multiple Response Permutation Procedure analysis. Apparently, the presence of the aquatic macrophytes is not the only factor influencing the distribution of littoral fish assemblages in the Fragosos River. Littoral fish seem to be taking advantage of low- to medium-sized macrophyte stands, but few species used maximum-sized stands.
\end{abstract}

Keywords: fish assemblage, aquatic macrophytes, Itá reservoir, Upper Uruguay River.

\section{Estrutura da assembleia de peixes litorâneos em um tributário represado: os efeitos da presença de macrófitas (região subtropical, Brasil)}

\begin{abstract}
Resumo
Buscando-se avaliar os efeitos da presença de macrófitas na estrutura da assembleia de peixes litorâneos, foram realizadas coletas mensais (setembro/2006 a agosto/2007) na região lêntica de um tributário represado pelo reservatório de Itá (Rio Uruguai, Brasil), o Rio Fragosos. As amostragens foram realizadas com uma rede de arrasto na zona litorânea dentro do banco de macrófitas e em áreas sem macrófitas. Os peixes coletados foram identificados e submetidos a uma biometria. Para caracterizar os locais amostrados, foi avaliada a qualidade da água e estimada a área de cobertura do banco. Foram capturados 5191 indivíduos durante todo o período de estudo. Os atributos da assembleia analisados variaram significativamente entre os meses e os locais amostrados, assim como a abundância das espécies Astyanax cf. bimaculatus, Astyanax fasciatus, Geophagus brasiliensis e Gymnotus carapo. A Análise de Correspondência Destendenciada mostrou uma forte segregação espacial e uma leve segregação temporal. Esses resultados foram confirmados pela análise de permutação múltipla - MRPP. Aparentemente, a presença das macrófitas aquáticas não é o único fator que está influenciando a distribuição da assembleia de peixes do rio Fragosos, a qual parece estar se beneficiando do banco de macrófitas em períodos de baixa e média cobertura vegetal, sendo que poucas espécies utilizam esse ambiente quando o banco se torna maior.
\end{abstract}

Palavras-chave: assembleia de peixes, macrófitas aquáticas, reservatório de Itá, Alto Rio Uruguai. 


\section{Introduction}

The importance of the littoral zone to aquatic organisms has been demonstrated in many aquatic systems (Vono and Barbosa, 2001; Lewin et al., 2004; Tolonen et al., 2005). The littoral zone provides different microhabitats with varying degrees of complexity, including the presence or absence of aquatic vegetation.

Aquatic macrophytes add complexity to aquatic systems because of their plant morphology (the structures of roots, stems, and leaves), creating a unique substrate for macroinvertebrate and zooplankton fixation (Dibble and Thomaz, 2006) and consequently promoting an enhancement of food availability for fish (Casatti et al., 2003; Dibble and Thomaz, 2006; Pelicice and Agostinho, 2006). Additionally, they provide refuge from predators to young and small adult fish (Meschiatti et al., 2000; Agostinho et al., 2003, 2007; Neiff et al., 2009). Thus, the high complexity provided by the presence of macrophytes can promote higher fish diversity, abundance and species richness (Petry et al., 2003; Pelicice et al., 2005; Agostinho et al., 2007; Dibble and Pelicice, 2010), influencing the fish assemblage structure of littoral habitats.

However, the presence of aquatic macrophytes can also alter the physicochemical characteristics of water, especially when present in high densities, and can establish dissolved oxygen, $\mathrm{pH}$ and ammonia conditions that may limit the presence of some fish species (Miranda et al., 2000; Miranda and Hodges, 2000; Petr, 2000).

Although many studies have shown the importance of aquatic macrophytes to fish assemblage structure, few studies have conducted simultaneous sampling in macrophyte areas and open areas to allow for a true comparison of these habitats (Agostinho et al., 2007).

In our study, we carried out sampling in the littoral zones of an impounded tributary in areas with and without the presence of floating macrophytes. We tested the hypothesis that the presence of aquatic vegetation (macrophytes) influences littoral fish assemblage structure. To test this hypothesis, we assessed which factors explained the structure of the littoral fish assemblage at the impounded tributary of the Itá Reservoir by analyzing the presence or absence of macrophytes, the percentage of macrophyte cover, season, and environmental variables.

\section{Material and Methods}

To evaluate fish assemblage structure associated with a macrophyte stand at the Itá Reservoir, located in the Upper Uruguay River (between Santa Catarina and Rio Grande do Sul states, Brazil; $27^{\circ} 14^{\prime} \mathrm{S}$ and 52 $11^{\prime} \mathrm{W}$ ), we selected the Fragosos River, an impounded tributary of the lower portion of the reservoir. In this reservoir, macrophyte stands are usually found near tributaries, where a rich nutrient water flow from the surrounding watershed enters the lentic waters of the lake. Aquatic macrophytes at the Itá Reservoir are controlled by the dam managers, who enclose the floating macrophytes with cables so that the plants do not spread over the lake. Additionally, some plants are periodically removed mechanically to control the macrophyte stand size. During the course of the study, no macrophytes removal was conducted.

Fish sampling occurred monthly between September, 2006 and August, 2007. The macrophyte stands found at the Fragosos River during this period varied greatly in size, but the most abundant species during the study period was the water hyacinth, Eichhornia crassipes (Martius).

Fish were collected using a beach seine (12 $\mathrm{m}$ long $\times 3 \mathrm{~m}$ high, with a $8 \mathrm{~mm}$ mesh size), and sampling was conducted in the littoral zone in three replicates inside and outside the macrophyte stand $(\mathrm{M})$ and in an area with no macrophytes $(\mathrm{O})$. Inside the macrophyte stand, sampling was conducted in a way that a match of macrophytes was caught by the seine, the macrophytes were then removed by hand, and fish enclosed by the seine were collected. Sampling was conducted during the morning between 0800 and 1200 hours. All fish collected were identified, counted, measured $(\mathrm{mm})$, and weighed $(\mathrm{g})$. Voucher specimens were deposited in the Ichthyological Collection of the Universidade Estadual de Londrina (Brazil) and in the Laboratório de Biologia e Cultivo de Peixes de Água Doce (LAPAD) of the Universidade Federal de Santa Catarina (UFSC, Brazil).

To characterize sampling sites (open and macrophyte areas) in each month, environmental variables (water temperature, $\mathrm{DO}$, and $\mathrm{pH}$ ) were measured after fish sampling at the sub-surface area inside and outside of the macrophyte stand. Water level data were obtained from the dam operator, Tractebel Energia (Florianópolis, SC, Brasil). The percentage of macrophyte cover was estimated visually and the macrophyte stand was photographed every month to check post-sampling. The percentage of macrophyte cover of the stand was classified into four categories based on the photographic register: 0 (absence of macrophytes), 1 (low macrophyte cover; $<35 \%$ of the maximum), 2 (medium macrophyte cover; $35 \%$ to $70 \%$ of the maximum), and 3 (maximum macrophyte cover during the study period).

\subsection{Statistical analyses}

Fish assemblage attributes (species richness, Shannon diversity and abundance) were obtained using the software Primer 6 Beta. To perform all the analyses, fish abundance data were logarithmically transformed $\left(\log _{10} x+1\right)$.

To summarize fish assemblage structure throughout the sampling months and areas, a Detrended Correspondence Analysis (DCA) was used. To minimize the effect of rare species in the ordination, only species with a frequency of occurrence greater than $6 \%$ during the whole study period were used in the analyses. The DCA was selected because it can remove some sources of error such as the arch effect and the scale contraction effect and is considered suitable for nonlinear data.

To statistically test for the differences of fish assemblages observed (group separation) and to corroborate the results of the DCA, the same fish abundance data used for the DCA was used for the Multiple Response Permutation 
Procedure (MRPP; PC-Ord Software 5.0). Following this test, the T-value was used to determine the consistency of the classification, the A-value was used to evaluate the homogeneity between the groups, and the P-value was used to evaluate the statistical significance (McCune and Grace, 2002).

A Principal Component Analysis (PCA) was used to select the most representative environmental variables (water-quality and habitat variables), which were then correlated to fish assemblage attributes and to the abundance of the six most abundant species using Pearson's correlation.

Environmental variable data, except $\mathrm{pH}$, were logarithmically transformed $\left(\log _{10} x+1\right)$. For all analyses, $\alpha=0.05$ was used as the level of statistical significance.

\section{Results}

A total of 5,191 fish was captured during the study period. The six most abundant species accounted for $86 \%$ of the total amount caught: Astyanax fasciatus Cuvier ( $\mathrm{n}=1466)$, Moenkhausia sp. $(\mathrm{n}=885)$, Geophagus brasiliensis Quoy \& Gaimard $(\mathrm{n}=641)$, A. cf. bimaculatus Linnaeus ( $\mathrm{n}=580)$, Gymnotus carapo Linnaeus ( $\mathrm{n}=498)$, and Steindachnerina brevipinna Eigenmann \& Eigenmann $(\mathrm{n}=390)$. In general, fish capture was higher in the open area than inside the macrophyte stand $(\mathrm{O}=3323 ; \mathrm{M}=1868)$. From the six most abundant species captured during this study, G. carapo was the only one which was captured only inside the macrophyte stand.

Fish assemblage was composed of 26 species distributed in six orders and 12 families (Table 1). Characiformes was the most important order (14 species). Almost the same number of species was captured inside and outside the macrophyte stand during the study period $(\mathrm{O}=19$; $M=18)$. The Shannon diversity index was slightly higher inside the macrophyte stand $\left(\mathrm{H}_{(\log 2)}=2.955\right)$ than in the open area $\left(\mathrm{H}_{(\log 2)}^{\prime}=2.649\right)$.

Only the first two axes generated by the DCA applied to fish data collected were retained for interpretation (Figure 1). The first axis of DCA (21.0\%) showed a clear spatial segregation, where samples inside the macrophyte stand were strongly influenced by a high capture rate of the Gymnotiformes species Eigenmannia virescens Valenciennes $(\mathrm{r}=0.414 ; \mathrm{P}<0.05)$ and G. carapo $(\mathrm{r}=0.669 ; \mathrm{P}<0.05)$, while samples in the open area were characterized by the highest abundance of Apareiodon affinis Steindachner $(\mathrm{r}=-0.454 ; \mathrm{P}<0.05)$. Axis $2(13.2 \%)$ showed slight temporal segregation, where sampling conducted in the spring and summer was characterized by the highest abundances of G. brasiliensis $(\mathrm{r}=0.586 ; \mathrm{P}<0.05)$ and sampling conducted during fall and winter was characterized by the highest abundances of Moenkhausia sp. $(\mathrm{r}=0.436$; $\mathrm{P}<0.05)$.

MRPP analysis showed significant differences between groups, confirming the fish assemblage segregation showed by DCA. According to MRPP, there was a higher temporal

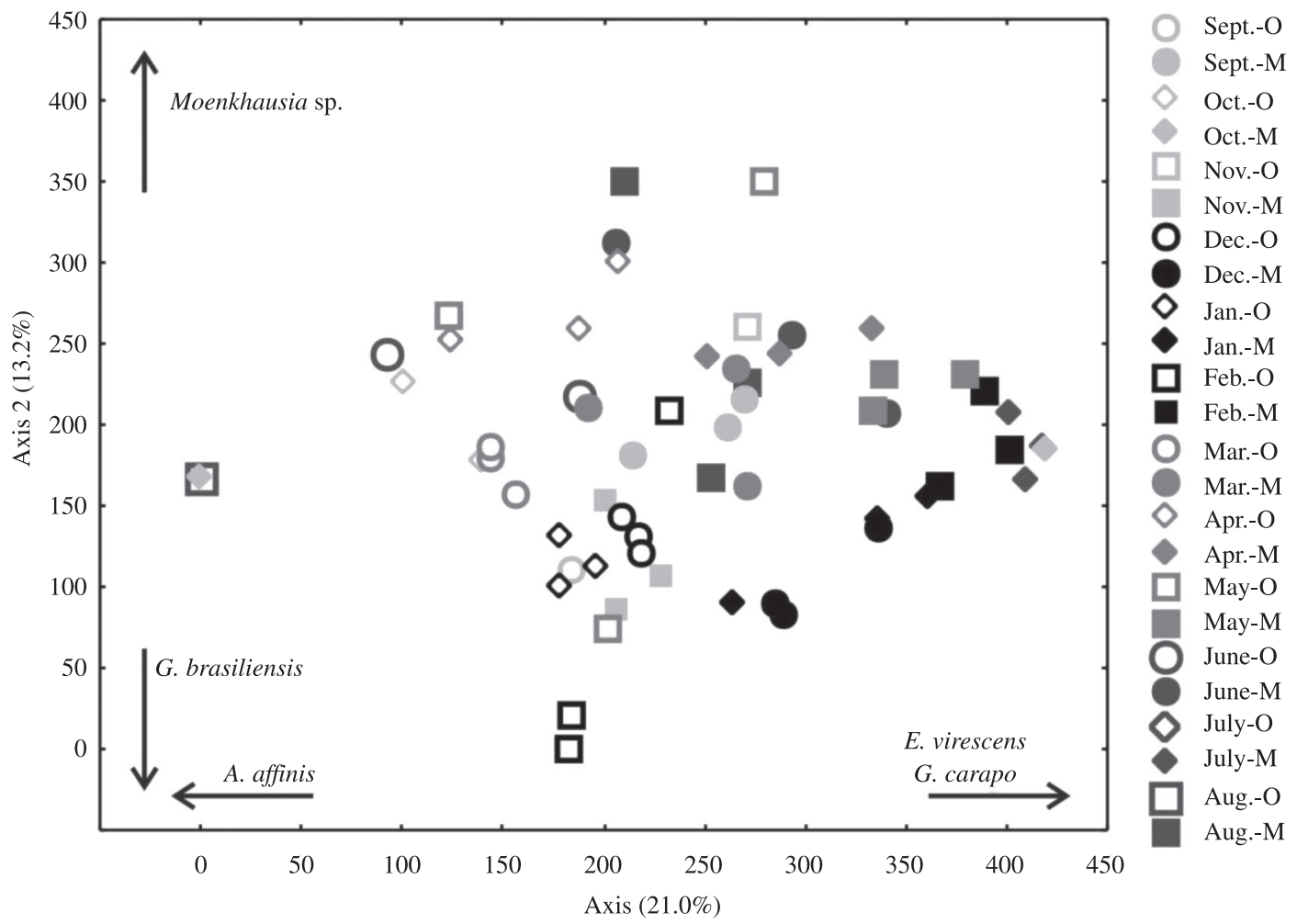

Figure 1. DCA showing sampling distribution in relation to species composition (open marks = samples from the open area; closed marks $=$ samples from the macrophyte area). 
Table 1. Fish species recorded in the Fragosos River with their frequency of occurrence (FO\%) and the total number of individuals (N) captured between September 2006 and August 2007 in each habitat $(\mathrm{O}=$ open area; $\mathrm{M}=$ macrophyte area).

\begin{tabular}{|c|c|c|c|c|c|c|}
\hline Order & Family & Species & FO\% & $\mathbf{N}$ & $\mathbf{O}$ & $\mathbf{M}$ \\
\hline \multicolumn{7}{|c|}{ ATHERINIFORMES } \\
\hline & Atherinidae & Odontesthes perugiae & 0.9 & 3 & 3 & 0 \\
\hline \multicolumn{7}{|c|}{ CHARACIFORMES } \\
\hline & Acestrorhynchidae & Acestrorhynchus pantaneiro & 11.1 & 22 & 10 & 12 \\
\hline \multirow{7}{*}{\multicolumn{2}{|c|}{ Characidae }} & Astyanax cf. bimaculatus & 50.0 & 580 & 300 & 280 \\
\hline & & Astyanax fasciatus & 45.8 & 1466 & 1309 & 157 \\
\hline & & Bryconamericus iheringii & 11.1 & 29 & 11 & 18 \\
\hline & & Bryconamericus stramineus & 5.6 & 72 & 72 & 0 \\
\hline & & Moenkhausia sp. & 40.3 & 885 & 489 & 396 \\
\hline & & Odontostilbe aff. pequira & 46.9 & 301 & 297 & 4 \\
\hline & & Serrasalmus maculatus & 26.4 & 79 & 21 & 58 \\
\hline & Crenuchidae & Characidium zebra & 2.8 & 3 & 1 & 2 \\
\hline & Curimatidae & Steindachnerina brevipinna & 27.8 & 390 & 297 & 93 \\
\hline \multirow{2}{*}{\multicolumn{2}{|c|}{ Erythrinidae }} & Hoplias lacerdae & 8.3 & 6 & 0 & 6 \\
\hline & & Hoplias malabaricus & 15.3 & 24 & 0 & 24 \\
\hline & Parodontidae & Apareiodon affinis & 18.1 & 43 & 43 & 0 \\
\hline \multicolumn{7}{|c|}{ CYPRINODONTIFORMES } \\
\hline & Poeciliidae & Phalloceros caudimaculatus & 1.4 & 1 & 1 & 0 \\
\hline \multicolumn{7}{|c|}{ GYMNOTIFORMES } \\
\hline & Gymnotidae & Gymnotus carapo & 41.7 & 498 & 0 & 498 \\
\hline & Sternopygidae & Eigenmannia virescens & 20.8 & 106 & 0 & 106 \\
\hline \multicolumn{7}{|c|}{ PERCIFORMES } \\
\hline \multirow{7}{*}{\multicolumn{2}{|c|}{ Cichlidae }} & Crenicichla celidochilus & 1.4 & 1 & 1 & 0 \\
\hline & & Crenicichla minuano & 6.9 & 10 & 10 & 0 \\
\hline & & Crenicichla missioneira & 1.4 & 1 & 0 & 1 \\
\hline & & Crenicichla vittata & 8.3 & 19 & 13 & 6 \\
\hline & & Geophagus brasiliensis & 38.9 & 641 & 440 & 201 \\
\hline & & Gymnogeophagus gymnogenys & 4.2 & 4 & 4 & 0 \\
\hline & & Oreochromis niloticus & 1.4 & 1 & 1 & 0 \\
\hline \multicolumn{7}{|c|}{ SILURIFORMES } \\
\hline & Auchenipteridae & Parauchenipterus galeatus & 5.6 & 5 & 0 & 5 \\
\hline & Loricaridae & Hypostomus commersoni & 1.4 & 1 & 0 & 1 \\
\hline
\end{tabular}

segregation $(\mathrm{T}=-10.26 ; \mathrm{A}=0.18 ; \mathrm{P}<0.05)$ than spatial segregation $(\mathrm{T}=-9.03 ; \mathrm{A}=0.04 ; \mathrm{P}<0.05)$.

Together, the first two axis of PCA explained most of the variability of the environmental variables (71.3\%). Axis 1 (eigenvalue $=2.00$ ) explained $42.2 \%$ of the variation in the data and separated $\mathrm{pH}$ values from macrophyte cover (Figure 2). In general, samples from the maximum macrophyte stand size had the lowest $\mathrm{pH}$ values, whereas samples in the open area and from macrophyte stands of medium and small sizes had higher $\mathrm{pH}$ values. Axis 2 (eigenvalue $=1.54$ ) explained $29.1 \%$ of the variation and showed some seasonal variation (Figure 2), where samples collected in the fall and winter had the highest values of dissolved oxygen but samples collected in the spring and summer had the highest water temperature values.
Pearson's correlation showed a strong positive correlation between macrophyte cover and the abundance of G. carapo $(\mathrm{r}=0.65 ; \mathrm{P}<0.05)$. A positive correlation was also observed between the water temperature and species richness $(\mathrm{r}=0.45 ; \mathrm{P}<0.05)$, total fish abundance $(\mathrm{r}=0.33 ; \mathrm{P}<0.05)$, fish diversity $(\mathrm{r}=0.42 ; \mathrm{P}<0.05)$ and the abundance of $A$. cf. bimaculatus $(\mathrm{r}=0.48 ; \mathrm{P}<0.05), G$. brasiliensis $(\mathrm{r}=0.47 ; \mathrm{P}<0.05)$, and $S$. brevipinna $(\mathrm{r}=0.39 ; \mathrm{P}<0.05)$. A positive correlation was also observed between the abundance of Moenkhausia sp. and water level ( $\mathrm{r}=0.27$; $\mathrm{P}<0.05)$, S. brevipinna and $\mathrm{pH}(\mathrm{r}=0.28 ; \mathrm{P}<0.05)$, and G. brasiliensis and dissolved oxygen $(\mathrm{r}=0.27 ; \mathrm{P}<0.05)$ and $\mathrm{pH}(\mathrm{r}=0.41 ; \mathrm{P}<0.05)$. A negative correlation was observed between the macrophyte cover and the abundance of $A$. fasciatus ( $\mathrm{r}=-0.30 ; \mathrm{P}<0.05)$. Pearson's correlation also showed a negative correlation between the abundance 


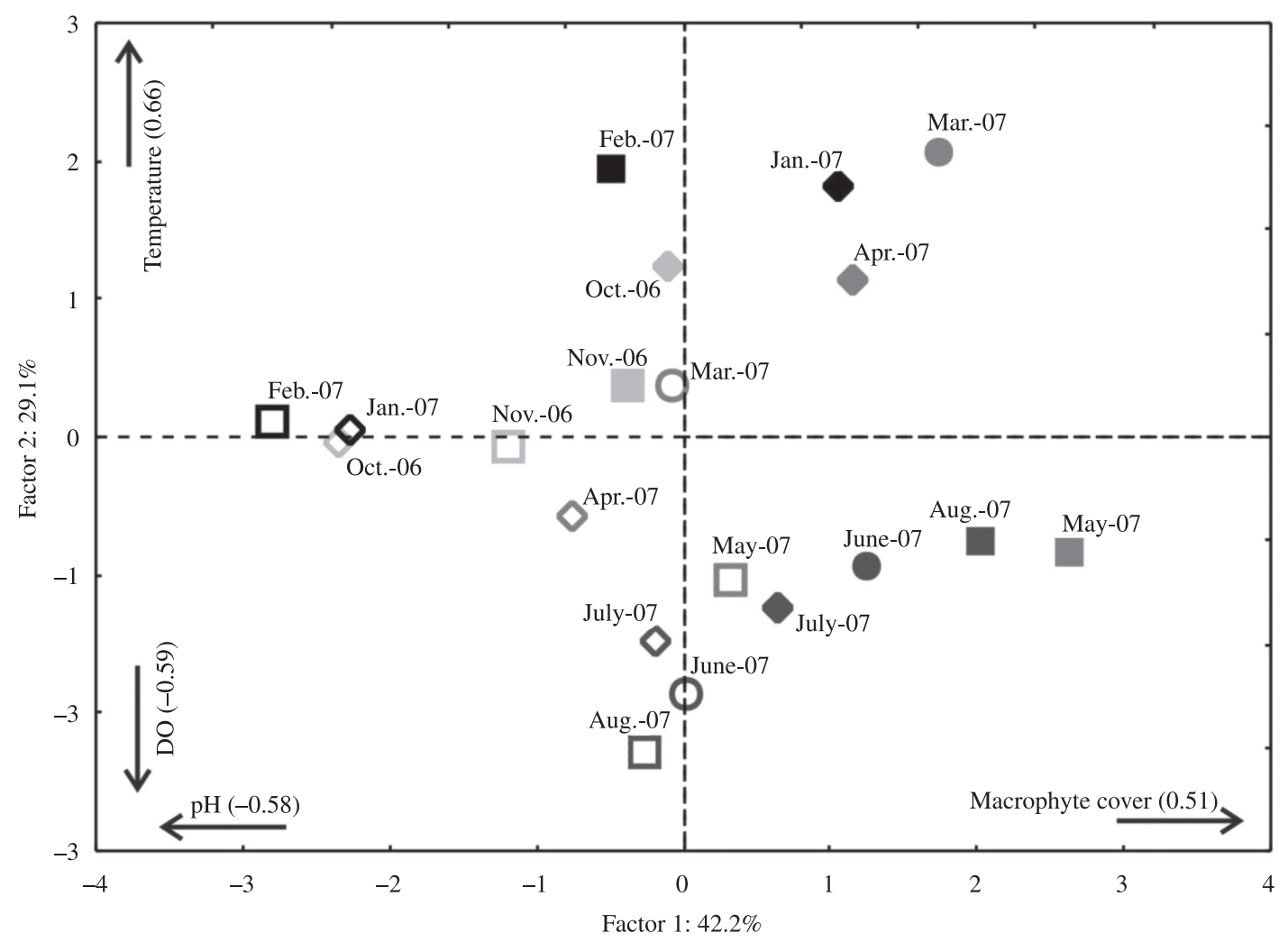

Figure 2. Results of PCA applied to summarize the environmental and habitat variables registered during the study period. Arrows indicate variables correlated with each axis and values in brackets represent significant effect (open marks $=$ samples from the open area; closed marks = samples from the macrophyte area).

of $G$. carapo and dissolved oxygen $(\mathrm{r}=-0.51 ; \mathrm{P}<0.05)$ and $\mathrm{pH}(\mathrm{r}=-0.29 ; \mathrm{P}<0.05)$.

\section{Discussion}

Although aquatic macrophytes can promote a structurally varied habitat for aquatic communities, the presence of these plants is not the only factor influencing fish assemblage structure in the Fragosos River. Of all the species and assemblage attributes analyzed, only $G$. carapo seemed to be directly influenced by the presence of the $E$. crassipes. Other variables, such as sampling month and water temperature (which are both related to seasonal fluctuations) seemed to influence fish assemblage structure in the study area.

Littoral fish assemblages in the Fragosos River were dominated by small- and medium-sized species of Characiformes, Perciformes and Gymnotiformes, which comprised more than $80 \%$ of the total fish captured. The higher abundance of Characiformes species, especially in habitats where macrophytes are present, has been documented in many other Neotropical river basins (Delariva et al., 1994; Meschiatti et al., 2000; Casatti et al., 2003; Petry et al., 2003; Pelicice et al., 2005; Pacheco and Da-Silva, 2009). The species G. brasiliensis (Perciformes) and G. carapo (Gymnotiformes) are also very common in macrophyte areas (Vono and Barbosa, 2001; Petry et al., 2003). However, in our study, only G. carapo was more abundant in such areas, while the abundance of $G$. brasiliensis seemed to vary greatly across areas showing a strong seasonal influence.

The important role of macrophytes in structuring fish assemblages has been documented by various previous studies (Chick and McIvor, 1997; Weaver et al., 1997; Grenouillet and Pont 2001; Vono and Barbosa, 2001; Pelicice et al., 2005). However, few studies have simultaneously compared samples from macrophyte areas to open areas. Agostinho et al. (2007) found that fish diversity and abundance were higher inside macrophyte stands than in open areas, although the position inside the macrophyte stand also influenced these attributes. Fish diversity and abundance were higher at the border of the stand than in the middle (Agostinho et al., 2007).

In our study, we observed that the Shannon diversity index and the abundance of few species, such as G. carapo, E. virescens, Hoplias malabaricus (Bloch, 1794) and Parauchenipterus galeatus (Linnaeus, 1766) were higher in the macrophyte area than in the open area. In contrast to results from previous studies (Pelicice et al., 2005; Agostinho et al., 2007), total fish abundance, species richness, and the abundance of some species seemed to be highest in the open area. For most attributes, it was not possible to detect the effect of the macrophyte cover on 
these variations, which may suggest that factors other than macrophyte presence may be affecting fish assemblage structure.

Pearson's correlation showed a negative effect of macrophyte cover only on the abundance of $A$. fasciatus and a positive effect only on the abundance of G. carapo. This positive effect of macrophyte cover on the abundance of $G$. carapo may be related to the biological and ecological aspects of this species. G. carapo is a multiple spawner species which exhibits territorial, parental care and building nests behavior (Campos-da-Paz, 2003; Cognato and Fialho, 2006). Besides that, it has a carnivorous feeding habit with a preference for small aquatic animals (Albert and Crampton, 2003), a lateral compressed body and a superior mouth (Campos-da-Paz, 2003). All these characteristics suggest an interaction between feeding, reproduction and the habitat selection of this species, which may be favored in dense macrophyte stands.

When analyzing macrophyte cover (or density), some previous studies (Vono and Barbosa, 2001; Pelicice et al., 2005) have shown that the highest fish abundances and species diversity values are observed at macrophyte stands of high density. However, it seems that the most common finding is that intermediate densities of macrophytes can maintain the highest fish densities and species richness (Dibble et al., 1996; Miranda and Pugh, 1997; Miranda and Hodges, 2000).

Because macrophyte cover varied greatly during our study, the presence or absence of macrophytes did not seem to be the only factor influencing the structure of littoral fish assemblages. Although fish assemblage attributes showed differences between the areas, the highest values of the attributes studied were observed mainly in the open areas or during periods of intermediate and low macrophytes cover. Only the Shannon diversity index showed high values inside the macrophyte stand, no matter what the intensity of macrophyte cover was (low, intermediate or high).

The results obtained in our study suggest that the presence of macrophyte stands at low densities permits a more intense use of the stand by different fish species that were not using this habitat in other situations (intermediate to high macrophyte densities).

Lewin et al. (2004) studied the distribution of juvenile fish in littoral areas of a lake in Germany and observed that the distribution pattern of some species was shaped by refuge-seeking behavior toward physically complex structures in a diel cycle. During the day, fish biomass was higher in woody structures in the littoral zone, while fish distribution during the night varied between species and was mainly related to prey availability between open and structured littoral habitats. The littoral zones of lakes and reservoirs have varying characteristics that may influence fish distribution, such as depth, wave action, bottom substrate, presence or absence of aquatic macrophytes, density of macrophytes, and presence of other natural structures (trees, woody debris or stones) (Vono and Barbosa, 2001; Lewin et al., 2004; Tolonen et al., 2005; Warfe and Barmuta, 2006). These characteristics may have various influences on different species, which may seek food, refuge or good environmental conditions depending on size, feeding behavior or tolerance to physicochemical variation.

Fish assemblages observed in our study seemed to take advantage of these varying characteristics of the littoral zone. Although we did not measure all characteristics of the littoral habitats of the Fragosos River and we did not evaluate diel cycles, the presence or absence of aquatic macrophytes, and the variation of abiotic variables mediated by macrophytes, seemed to promote some of the variation on fish assemblage structure observed in our study, as shown by Pearson's correlation.

Strong positive correlations were observed between water temperature and species richness, total fish abundance, fish diversity, and the abundance of $A$. cf. bimaculatus, G. brasiliensis, and S. brevipinna. Additionally, a positive correlation was also observed between the abundance of some species (Moenkhausia sp., A. fasciatus, and $G$. brasiliensis) and specific environmental variables (water level, dissolved oxygen, and $\mathrm{pH}$ ). A negative correlation to some environmental variables (DO and $\mathrm{pH}$ ) was observed only for the abundance of $G$. carapo, which suggests that this species can tolerate adverse physicochemical conditions. This tolerance was also observed by Cognato and Fialho (2006), who found that females of this species presented an increase in gonadal development correlated to a decrease in dissolved oxygen levels.

Villamagna and Murphy (2010) provided a review of water hyacinth studies based on impacts of water quality and on different ecological communities. As suggested by these authors, fish may benefit from highly fragmented macrophyte stands, which promote a higher edge-to-core ratio, decreasing the negative effect of dense non-fragmented stands (low dissolved oxygen concentrations) on fish species. Furthermore, higher densities and diversity of macroinvertebrates and zooplankton are observed along the edges of the floating macrophyte stands, thereby providing a suitable environment for juvenile and small-sized fish species (Villamagna and Murphy, 2010).

Thus, we can conclude that the fish assemblage structure of the Fragosos River is influenced by the presence of macrophytes in the area. We could observe that some fish species are using mainly the open area (A. affinis) while others are using mainly the macrophyte stand (E. virescens and $G$. carapo). However, in general, the fish assemblage of the Fragosos River is probably benefiting from the presence of macrophytes in the littoral zone in low- to medium-sized stands where fish can probably find suitable environments to meet their ecological needs.

Acknowledgements - The authors would like to thank coworkers from LAPAD for their help in field sampling. We are also thankful to Dr. D.A. Reynalte-Tataje for his statistical support and the anonymous reviewers for helpful comments and suggestions on the manuscript. This work was funded by Tractebel Energia as part of the project "Monitoramento e Manejo da Ictiofauna do Alto Rio Uruguai." S. Hermes-Silva acknowledges a doctoral scholarship and E. Zaniboni-Filho acknowledges a research productivity grant, both provided by the Conselho Nacional de Desenvolvimento Científico e Tecnológico of the Brazilian Federal Government (CNPq). 


\section{References}

AGOSTINHO, AA., GOMES, LC. and JULIO JUNIOR, HF., 2003. Relações entre macrófitas aquáticas e fauna de peixes. In THOMAZ, SM. and BINI, LM. (Eds.). Ecologia e Manejo de Macrófitas Aquáticas. Maringá: EDUEM. p. 261-279.

AGOSTINHO, AA., THOMAZ, SM., GOMES, LC. and BALTAR, S., 2007. Influence of the macrophyte Eichhornia azurea on fish assemblage of the Upper Parana River floodplain (Brazil). Aquatic Ecology, vol. 41, p. 611-619. http://dx.doi.org/10.1007/ s10452-007-9122-2

ALBERT, JS. and CRAMPTON, WGR., 2003. Seven new species of the Neotropical electric fish Gymnotus (Teleostei: Gymnotiformes) with redescription of G. carapo (Linnaeus). Zootaxa, vol. 287, p. 1-54.

CAMPOS-DA-PAZ, R., 2003. Family Gymnotidae. In REIS, RE., KULLANDER, SO. and FERRARIS JUNIOR, CJ. (Orgs.). Check list fo the freshwater fishes of South and Central America. Porto Alegre: EDIPUCRS. p. 483-486.

CASATTI, L., MENDES, HF. and FERREIRA, KM., 2003. Aquatic macrophytes as feeding site for small fishes in the Rosana Reservoir, Paranapanema River, Southeastern Brazil. Brazilian Journal of Biology, vol. 63, no. 2, p. 213-222. http://dx.doi. org/10.1590/S1519-69842003000200006

COGNATO, DP. and FIALHO, CB., 2006. Reproductive biology of a population of Gymnotus Aff. carapo from southern Brazil. Neotropical Ichthyology, vol. 4, no. 3, p. 339-348. http://dx.doi. org/10.1590/S1679-62252006000300005

CHICK, JH. and McIVOR, CC., 1997. Habitat selection by three littoral zone fishes: Effects of predation pressure, plant density and macrophyte type. Ecology of Freshwater Fish, vol. 6, p. 27-35. http://dx.doi.org/10.1111/j.1600-0633.1997.tb00139.x

DELARIVA, RL., AGOSTINHO, AA., NAKATANI, K. and BAUNGARTNER, G., 1994. Ichthyofauna associated to aquatic macrophytes in the Upper Paraná River floodplain. Revista UNIMAR, vol. 16 , p. 41-60.

DIBBLE, ED., KILLGORE, KJ. and HARREL SL., 1996. Assessment of fish-plant interactions. In MIRANDA LE. and DEVRIES, DR. Multidimensional approaches to reservoir fisheries management. Bethesda: American Fisheries Society Symposium 16. p. 357-372.

DIBBLE, ED. and THOMAZ, SM., 2006. A simple method to estimate spatial complexity in aquatic plants. Brazilian Archives of Biology and Technology, vol. 49, p. 421-428. http://dx.doi. org/10.1590/S1516-89132006000400010

DIBBLE, ED. and PELICICE, FM., 2010. Influence of aquatic plant-specific habitat on an assemblage of small neotropical floodplain fishes. Ecology of Freshwater Fish, vol. 19, p. 381-389. http://dx.doi.org/10.1111/j.1600-0633.2010.00420.x

GRENOUILLET, G. and PONT, D., 2001. Juvenile fishes in macrophyte beds: influence of food resources, habitat structure and body size. Journal of Fish Biology, vol. 59, p. 939-959. http:// dx.doi.org/10.1111/j.1095-8649.2001.tb00163.x

LEWIN, WC., OKUN, N. and MEHNER, T., 2004. Determinants of the distribution of juvenile fish in the littoral area of a shallow lake. Freshwater Biology, vol. 49, p. 410-424. http://dx.doi. org/10.1111/j.1365-2427.2004.01193.x

McCUNE, B. and GRACE, JB., 2002. Analysis of Ecological Communities. Gleneden Beach: MjM Software Design. 300 p.

MESCHIATTI, AJ., ARCIFA, MS. and FENERICH-VERANI, N., 2000. Fish communities associated with macrophytes in
Brazilian floodplain lakes. Environmental Biology of Fishes, vol. 58, p. 133-143. http://dx.doi.org/10.1023/A:1007637631663

MIRANDA, LE. and PUGH, LL., 1997. Relationship between vegetation coverage and abundance, size and diet of juvenile Large Mouth Bass during winter. North American Journal of Fisheries Management, vol. 17, p. 601-610. http://dx.doi.org/10.1577/15488675(1997)017<0601:RBVCAA >2.3.CO;2

MIRANDA, LE., DRISCOLL, MP. and ALLEN, MS., 2000. Transient physicochemical microhabitats facilitate fish survival in inhospitable aquatic plant stands. Freshwater Biology, vol. 44, p. 617-628. http://dx.doi.org/10.1046/j.1365-2427.2000.00606.x

MIRANDA, LE. and HODGES, KB., 2000. Role of aquatic vegetation coverage on hypoxia and sunfish abundance in bays of a eutrophic reservoir. Hydrobiologia, vol. 427, p. 51-57. http:// dx.doi.org/10.1023/A:1003999929094

NEIFF, JJ., NEIFF, AP. and VERON, MBC., 2009. The role of vegetated areas on fish assemblage of the Parana River floodplain: effects of different hydrological conditions. Neotropical Ichthyology, vol. 7, p. 39-48.

PACHECO, EB. and DA-SILVA, CJ., 2009. Fish associated with aquatic macrophytes in the Chacororé-Sinhá Mariana Lake system and Mutum River, Pantanal of MatoGrosso, Brazil. Brazilian Journal of Biology, vol. 69, no. 1, p. 101-108. http://dx.doi. org/10.1590/S1519-69842009000100012

PELICICE, FM. and AGOSTINHO, AA., 2006. Feeding ecology of fishes associated with Egeria spp. patches in a tropical reservoir, Brazil. Ecology of Freshwater Fish, vol. 15, p. 10-19. http://dx.doi. org/10.1111/j.1600-0633.2005.00121.x

PELICICE, FM., AGOSTINHO, AA. and THOMAZ, SM., 2005. Fish assemblages associated with Egeria in a tropical reservoir: investigating the effects of plant biomass and diel period. Acta Oecologica - International Journal of Ecology, vol. 27, p. 9-16.

PETR, T., 2000. Interactions between fish and aquatic macrophytes in inland waters: a review. FAO Fisheries Technical Paper, no. 396.

PETRY, P., BAYLEY, PB. and MARKLE, DF., 2003. Relationships between fish assemblages, macrophytes and environmental gradients in the Amazon River floodplain. Journal of Fish Biology, vol. 63, p. 547-579. http://dx.doi.org/10.1046/j.1095-8649.2003.00169.x

TOLONEN, KT., HOLOPAINEN, IJ., HAMALAINEN, H., RAHKOLA-SORSA, M., YLOSTALO, P., MIKKONEN, K. and KARJALAINEN, J., 2005. Littoral species diversity and biomass: concordance among organismal groups and the effects of environmental variables. Biodiversity and Conservation, vol. 14, p. 961-980. http://dx.doi.org/10.1007/s10531-004-8414-2

VILLAMAGNA, AM. and MURPHY, BR., 2010. Ecological and socio-economic impacts of invasive water hyacinth (Eichhorniacrassipes): a review. Freshwater Biology, vol. 55, p. 282-298. http://dx.doi.org/10.1111/j.1365-2427.2009.02294.x

VONO, V. and BARBOSA, FAR., 2001. Habitats and littoral zone fish community structure of two natural lakes in southeast Brazil. Environmental Biology of Fishes, vol. 61, p. 371-379. http://dx.doi.org/10.1023/A:1011628102125

WARFE, DM. and BARMUTA, LA., 2006. Habitat structural complexity mediates food web dynamics in a freshwater macrophyte community. Oecologia, vol. 150, p. 141-154. PMid:16932971. http://dx.doi.org/10.1007/s00442-006-0505-1

WEAVER, MJ., MAGNUSON, JJ. and CLAYTON, MK., 1997. Distribution of littoral fishes in structurally complex macrophytes. Canadian Journal of Fisheries and Aquatic Sciences, vol. 54, p. 2277-2289. http://dx.doi.org/10.1139/cjfas-54-10-2277 
